\title{
PENDAPATAN DAN KESEJAHTERAAN RUMAH TANGGA PETANI PADI LADANG DI KECAMATAN SIDOMULYO KABUPATEN LAMPUNG SELATAN
}

\author{
(Income and welfare of upland rice farmers in Sidomulyo Sub-district Regency of \\ Southern Lampung)
}

Wardiah Nurul Khasanah, Ktut Murniati, Sudarma Widjaya

Jurusan Agribisnis, Fakultas Pertanian, Universitas Lampung, Jl. Prof. Dr. Soemantri Brojonegoro No.1 Bandar Lampung 35141, Telp. 081273887101,e-mail: wardiahnurul29@gmail.com

\begin{abstract}
The purposes of this research are to determine income of upland rice farming, income level of farmer household, and household welfare level of upland rice farming. This research was conducted in Sidomulyo Sub-district, South Lampung District. The location is determined purposively by consideration that Sidomulyo Sub-district is one of the rice producing centers with the highest number of upland rice farmers in South Lampung District. The number of respondents in this study was 54 farmers. The methods of analysis used in this research are descriptive qualitative and quantitative analysis. The results showed that it is unprofitable rice farming with $R / C$ value over total cost of 0.69 . The income of farmers in rice field that has the greatest contribution is on farm (cultivation of rice fields and corn farming) income with percentage of 54.74 percent of total household income. The household welfare level of upland rice farming according to poverty criteria by Sajogyo (1976) belongs to sufficient and by the World Bank belongs to not poor category.
\end{abstract}

Key words: farm income, household income, household welfare, upland rice

\section{PENDAHULUAN}

Sektor pertanian khususnya tanaman pangan memberikan kontribusi sebesar 31,86 persen dari total Produk Domestik Regional Bruto (PDRB) Provinsi Lampung (BPS 2016). Tanaman pangan yang mempunyai porsi paling besar terhadap pendapatan nasional adalah padi. Padi merupakan bahan pangan pokok yang menjadi tolak ukur ketersediaan pangan bagi Indonesia (Damardjati dkk 2005).

Provinsi Lampung merupakan salah satu provinsi yang membudidayakan tanaman pangan, khususnya tanaman padi ladang. Hasil produksi padi ladang di Provinsi Lampung berbeda-beda setiap kabupaten/kota. Kabupaten Lampung Selatan memiliki produktivitas padi ladang tertinggi di Provinsi Lampung pada tahun 2015 yaitu sebesar $32,94 \mathrm{ku} / \mathrm{ha}$ dengan total produksi sebesar 27.099,74 ton. Salah satu kecamatan yang membudidayakan padi ladang adalah Kecamatan Sidomulyo (BPS Provinsi Lampung 2016).

Kecamatan Sidomulyo merupakan penghasil padi ladang terbesar ketiga di Kabupaten Lampung Selatan dengan luas panen sebesar 790 ha dengan jumlah produksi sebesar 2.378 ton (BPS Kabupaten Lampung Selatan 2016). Usahatani padi ladang digunakan untuk memenuhi kebutuhan konsumsi rumah tangga petani.

Perkembangan padi ladang di Kecamatan Sidomulyo tidak selalu berkembang sejalan dengan kondisi kesejahteraan petani. Salah satu faktor penyebab naik turunnya hasil produksi padi ladang adalah sarana produksi yang digunakan. Biayabiaya yang dikeluarkan untuk sarana produksi akan mempengaruhi pendapatan petani. Besarnya pendapatan yang diterima petani akan mempengaruhi pola konsumsi atau pengeluaran rumah tangga. Apabila biaya yang dikeluarkan tinggi, sedangkan penerimaannya rendah, maka pendapatan yang diterima petani juga rendah, sehingga mempengaruhi tingkat kesejahteraan rumah tangga petani tersebut.

Tingkat kesejahteraan petani di Kecamatan Sidomulyo masih berada di bawah rata-rata pendapatan nasional, karena pola konsumsi yang tidak diubah meskipun pendapatan mengalami peningkatan. Semakin tinggi pendapatan yang diterima, maka persentase pengeluaran pangan akan semakin bertambah. Hal ini menandakan bahwa, jika terjadi peningkatan pendapatan dan tidak merubah pola konsumsi pangan, maka rumah tangga dapat dikatakan tidak sejahtera. Jika peningkatan pendapatan dapat merubah pola 
konsumsi, maka rumah tangga tersebut dikatakan sejahtera (BPS 2016).

Hasil produksi padi ladang yang tinggi di Kecamatan Sidomulyo seharusnya dapat menjadikan petani hidup layak, karena pendapatan yang diperoleh petani adalah tinggi. Akan tetapi pada kenyataannya, produksi padi ladang yang tinggi masih belum mampu membuat petani hidup layak.

Kecamatan Sidomulyo memiliki jumlah keluarga pra sejahtera terbesar kedua setelah Kecamatan Natar yaitu 10.343 keluarga. Keluarga pra sejahtera adalah keluarga yang tidak dapat memenuhi tiga indikator kebutuhan dasar keluarga yaitu sandang, pangan, dan papan (Kantor Pemberdayaan Perempuan dan Keluarga Berencana Kabupaten Lampung Selatan 2016).

Pengukuran kesejahteraan dapat ditentukan berdasarkan kemampuan keluarga dalam memenuhi kebutuhan pangan, sandang, papan, dan kebutuhan yang bersifat kebendaan lainnya (Sukirno 2005), sedangkan mayoritas keluarga petani di Kecamatan Sidomulyo masih belum mampu memenuhi semua indikator tersebut. Kondisi tersebut bertolak belakang dengan fakta bahwa Kabupaten Lampung Selatan merupakan kabupaten yang menjadi sentra produksi padi.

Petani umumnya memiliki lahan yang relatif sempit, sehingga pendapatan dari usahatani saja sering tidak mencukupi kebutuhan dasar rumah tangga. Hal ini merupakan tolak ukur awal guna menilai tingkat kesejahteraan rumah tangga petani itu sendiri.

Berdasarkan uraian latar belakang, maka penelitian ini bertujuan mengetahui pendapatan usahatani, mengetahui pendapatan rumah tangga, dan mengetahui tingkat kesejahteraan rumah tangga petani padi ladang di Kecamatan Sidomulyo Kabupaten Lampung Selatan.

\section{METODE PENELITIAN}

Penelitian ini dilaksanakan dengan metode survei. Metode survei menurut Singarimbun dan Effendi (1995) adalah penelitian yang mengambil sampel dari suatu populasi dan menggunakan kuesioner sebagai alat pengumpulan data yang pokok. Penelitian dilakukan di Kecamatan Sidomulyo, Kabupaten Lampung Selatan. Lokasi ditentukan secara sengaja (purposive) dengan pertimbangan daerah sentra produksi padi ladang dengan jumlah petani padi ladang tertinggi. Pengambilan data dilakukan pada bulan Juli 2017. Jumlah responden pada penelitian ini sebanyak 54 responden dengan menggunakan rumus (Isaac dan Micheal 1995) sebagai berikut.

$\mathrm{n}=\frac{\mathrm{N} \mathrm{Z} \mathrm{S}^{2}}{\mathrm{Nd}^{2}+\mathrm{Z}^{2} \mathrm{~S}^{2}}$

Keterangan:

$\mathrm{n} \quad=$ Ukuran sampel

$\mathrm{N}=$ Ukuran populasi (petani)

$\mathrm{Z}=$ Tingkat kepercayaan $(95 \%=1,96)$

$S^{2}=$ Variasi sampel $(5 \%=0,05)$

$\mathrm{D}=$ Derajat penyimpangan $(5 \%=0,05)$

Analisis data yang digunakan untuk menghitung pendapatan usahatani diperoleh dengan menghitung selisih antara penerimaan yang diterima dari hasil usahatani dengan biaya produksi yang dikeluarkan dalam satu tahun. Pendapatan petani padi ladang dihitung dengan menggunakan rumus Soekartawi (1995):

$\pi=\mathrm{TR}-\mathrm{TC}$

Keterangan:

$\pi \quad=$ Keuntungan

$\mathrm{TR}=$ Total penerimaan $(\mathrm{Rp})$

$\mathrm{TC}=$ Total biaya $(\mathrm{Rp})$

Usahatani menguntungkan atau tidak secara ekonomi dapat dianalisis dengan menggunakan nisbah atau perbandingan antara penerimaan dengan biaya R/C (Revenue Cost Ratio). Nilai R/C rasio diperoleh menggunakan rumus :

$\mathrm{R} / \mathrm{C}=\frac{\mathrm{TR}}{\mathrm{TC}}$

Keterangan :

$\mathrm{R} / \mathrm{C}=$ Nisbah penerimaan dan biaya

$\mathrm{TR}=$ Total penerimaan $(\mathrm{Rp})$

$\mathrm{TC}=$ Biaya total $(\mathrm{Rp})$

Kriteria nilai $\mathrm{R} / \mathrm{C}$ rasio adalah:

(1) Jika $\mathrm{R} / \mathrm{C}>1$, maka usahatani padi yang diusahakan menguntungkan.

(2) Jika $\mathrm{R} / \mathrm{C}<1$, maka usahatani padi yang diusahakan mengalami kerugian.

(3) Jika $\mathrm{R} / \mathrm{C}=1$, maka usahatani padi yang diusahakan berada dalam titik impas (BEP).

Pendapatan rumah tangga diperoleh dengan cara menjumlahkan pendapatan keluarga yang berasal dari usahatani, non usahatani dan pendapatan luar 
pertanian (Rahim dan Hastuti 2008), dengan rumus sebagai berikut:

$\mathrm{P}_{\mathrm{rt}}=\mathrm{P}_{\text {usahatani padi }}+\mathrm{P}_{\text {usahatani non padi }}+\mathrm{P}_{\text {off farm }}+\mathrm{P}_{\text {non farm }}$

Keterangan :

$\mathrm{P}_{\mathrm{rt}} \quad=$ Pendapatan rumah tangga petani padi per-tahun

$\mathrm{P}_{\text {usahatani padi }}=$ Pendapatan dari usahatani padi

$\mathrm{P}_{\text {usahatani non padi }}=$ Pendapatan dari usahatani selain padi

$P_{\text {off farm }}=$ Pendapatan dari luar usahatani

$P_{\text {non farm }} \quad=$ Pendapatan dari luar pertanian

Metode analisis untuk mengukur tingkat kemiskinan rumah tangga digunakan analisis kualitatif dengan menggunakan indikator Bank Dunia dan Sajogyo. Bank Dunia menetapkan garis kemiskinan sebesar US\$ 1 per kapita per hari artinya dianggap miskin di dunia. Di negara manapun, individu tersebut berada adalah yang memiliki pengeluaran kurang dari US\$ 1 per kapita per hari (Todaro 2000), sedangkan kriteria kemiskinan Sajogyo (1976), pengeluaran rumah tangga/kapita per tahun dikonversikan ke dalam ukuran setara beras per kilogram. Kriteria ini pernah dilakukan oleh Putri, Lestari, dan Nugraha (2013).

Pengeluaran/kapita/tahun $(\mathrm{Rp})=$

$\frac{\mathrm{C}}{\sum \text { keluarga }}$

Pengeluaran/kapita/tahun setara beras $(\mathrm{kg})=$

$$
\frac{\mathrm{C}}{\text { kapita }} / \text { th }
$$

harga beras

Klasifikasi kemiskinan menurut Sajogyo (1976) :

a. Paling miskin $=$ jika pengeluaran per anggota keluarga adalah $180 \mathrm{~kg}$ setara beras/tahun.

b. Miskin sekali $=$ jika pengeluaran per anggota keluarga adalah 181 - $240 \mathrm{~kg}$ setara beras/ tahun.

c. Miskin = jika pengeluaran per anggota keluarga adalah $241-320 \mathrm{~kg}$ setara beras/tahun.

d. Nyaris miskin $=$ jika pengeluaran per anggota keluarga adalah 321 - $480 \mathrm{~kg}$ setara beras/ tahun.

e. Cukup $=$ jika pengeluaran per anggota keluarga adalah $481-960 \mathrm{~kg}$ setara beras/tahun.

f. Hidup layak = jika pengeluaran per anggota keluarga adalah $>960 \mathrm{~kg}$ setara beras/tahun.

\section{HASIL DAN PEMBAHASAN}

\section{Karakteristik Responden Petani Padi Ladang}

Berdasarkan hasil penelitian yang dilakukan, diperoleh rata-rata umur petani di Kecamatan Sidomulyo sangat bervariasi berada pada kisaran antara 25 hingga 60 tahun. Menurut Mantra (2004), kelompok umur produktif berada pada kisaran 15-64 tahun. Oleh karena itu, umur petani responden termasuk dalam kelompok umur produktif.

Tingkat pendidikan yang paling banyak dicapai oleh petani padi ladang adalah tingkat pendidikan SD sebanyak 26 orang (48,14 persen). Jumlah anggota keluarga yang dimiliki oleh sebagian besar petani padi ladang adalah sebanyak lima sampai enam orang $(57,40$ persen). Petani padi ladang mempunyai pekerjaan lain di bidang pertanian offfarm seperti buruh tani dan pekerjaan lain di luar usahatani yaitu non-farm seperti berdagang, buruh bangunan dan satpam. Petani padi ladang memiliki luas lahan rata-rata $0,25-0,66$ ha sebanyak 90,74 persen. Status kepemilikan lahan petani padi ladang seluruhnya adalah sewa.

\section{Pendapatan Usahatani Padi Ladang}

Sistem usahatani padi ladang di Kecamatan Sidomulyo bukan sebagai mata pencaharian utama penduduk di Kecamatan Sidomulyo. Penerimaan yang dihasilkan dari usahatani padi ladang adalah Gabah Kering Giling (GKG). Penerimaan yang diperoleh petani padi ladang dari hasil usahatani padi ladang untuk 0,42 hektar dan satu hektar adalah Rp2.320.694,44 dan Rp5.569.666,67. Biaya produksi yang dikeluarkan oleh petani untuk satu musim tanam dalam 1 tahun terdiri dari biaya tunai (biaya benih, pupuk, pestisida, tenaga kerja luar keluarga, sewa lahan) dan biaya diperhitungkan (biaya penyusutan alat dan tenaga kerja dalam keluarga). Biaya terbesar yang harus dibayarkan petani untuk usahatani padi ladang adalah sewa lahan dan tenaga kerja.

Pendapatan rata-rata atas biaya tunai usahatani padi ladang di Kecamatan Sidomulyo per luas lahan 0,42 hektar sebesar Rp561.992,08, sedangkan pendapatan rata-rata atas biaya total sebesar Rp-1.060.027,71. Pendapatan rata-rata atas biaya tunai usahatani padi ladang per hektar sebesar Rp1.348.780,99, sedangkan pendapatan rata-rata atas biaya total sebesar Rp-2.544.066,51. Besarnya $\mathrm{R} / \mathrm{C}$ rasio atas biaya tunai sebesar 1,32 
yang artinya setiap $\mathrm{Rp} 1,00$ biaya yang dikeluarkan dalam usahatani padi ladang akan diperoleh penerimaan sebesar $\mathrm{Rp} 1,32$ dan $\mathrm{R} / \mathrm{C}$ rasio atas biaya total sebesar 0,69 artinya setiap $\mathrm{Rp} 1,00$ biaya yang dikeluarkan dalam usahatani padi ladang akan diperoleh penerimaan sebesar Rp0,69. Besarnya nisbah penerimaan dengan biaya tersebut menunjukkan bahwa usahatani padi ladang dilihat dari $\mathrm{R} / \mathrm{C}$ rasio atas biaya tunai menguntungkan, sedangkan $\mathrm{R} / \mathrm{C}$ rasio atas biaya total tidak menguntungkan.

Kondisi ini sejalan dengan penelitian Purba (2005) mengenai analisis pendapatan dan faktor-faktor yang mempengaruhi produksi cabang usahatani padi ladang di Kabupaten Karawang, diperoleh bahwa rata-rata penerimaan yang diperoleh petani dari hasil usahatani padi ladang di daerah penelitian sebesar Rp1.654.900 per hektar dan R/C biaya total sebesar 0,69 artinya $\mathrm{R} / \mathrm{C}<1$, maka dapat disimpulkan bahwa usahatani padi ladang di daerah penelitian tidak menguntungkan bagi petani. Syarat suatu usahatani dikatakan menguntungkan jika rasio $\mathrm{R} / \mathrm{C}$ atas biaya total lebih besar dari 1. Data rata-rata penerimaan, biaya, dan pendapatan usahatani padi ladang di Kecamatan Sidomulyo dapat dilihat pada Tabel 1.

\section{Pendapatan Usahatani Non Padi Ladang}

Usahatani padi ladang bukan merupakan mata pencaharian utama petani karena hanya dilakukan untuk memenuhi kebutuhan konsumsi pribadi. Usahatani selain usahatani padi ladang adalah usahatani jagung. Pendapatan dari hasil usahatani jagung adalah Rp29.280.092,59 per tahun atau $(53,83$ persen $)$ dari total pendapatan rumah tangga.

\section{Pendapatan Off Farm}

Salah satu sumber pendapatan petani padi ladang di Kecamatan Sidomulyo berasal dari kegiatan di luar usahatani, yaitu buruh tani. Pendapatan ratarata petani padi ladang dari kegiatan di luar usahatani (off farm) sebesar Rp23.222.222,22/ tahun.

\section{Pendapatan Non Farm}

Kegiatan non farm yang dilakukan petani responden di Kecamatan Sidomulyo antara lain satpam, berdagang, dan tukang bangunan. Pendapatan rata-rata petani dari aktivitas nonpertanian (non farm) per tahun di Kecamatan Sidomulyo sebesar Rp1.394.969,56/tahun atau sebesar 2,56 persen dari total pendapatan rumah tangga.

Pada rumah tangga petani, terdapat istri dan anak yang turut bekerja menopang ekonomi rumah tangga. Besarnya kontribusi usaha non pertanian mampu menjadikan petani memenuhi kebutuhan rumah tangga demi kelangsungan hidupnya. Menurut Agunggunanto, Saptanto, dan Apriliani (2011) menyimpulkan bahwa jumlah anggota keluarga yang bekerja juga mempengaruhi tingkat pendapatan keluarga.

Tabel 1. Rata-rata penerimaan, biaya, dan pendapatan usahatani padi ladang di Kecamatan Sidomulyo

\begin{tabular}{|c|c|c|c|c|c|c|}
\hline \multirow{2}{*}{ Uraian } & \multirow{2}{*}{ Satuan - } & \multicolumn{3}{|c|}{ Per luas lahan $(0,42 \mathrm{ha})$} & \multicolumn{2}{|c|}{ Per hektar (1 ha) } \\
\hline & & Jumlah & Harga (Rp) & Nilai (Rp) & Jumlah & Nilai (Rp) \\
\hline \multicolumn{7}{|l|}{ Penerimaan } \\
\hline Produksi & $\mathrm{Kg}$ & 703,24 & $3.300,00$ & $2.320 .694,44$ & $1.687,78$ & $5.569 .666,67$ \\
\hline \multicolumn{7}{|l|}{ Biaya Produksi } \\
\hline \multicolumn{7}{|l|}{ I. Biaya Tunai } \\
\hline Benih & $\mathrm{Kg}$ & 13,39 & $12.637,04$ & $169.195,88$ & 32,13 & $406.070,12$ \\
\hline Pupuk Ponska & $\mathrm{Kg}$ & 92,59 & $2.742,59$ & $253.943,76$ & 222,22 & $609.465,02$ \\
\hline Pupuk Urea & $\mathrm{Kg}$ & 61,57 & $2.157,41$ & $132.840,36$ & 147,78 & $318.816,87$ \\
\hline Pupuk TSP & $\mathrm{Kg}$ & 45,19 & $2.624,07$ & $118.569,27$ & 108,44 & $284.566,26$ \\
\hline Biaya Pestisida & $\mathrm{Rp}$ & & & $144.829,01$ & & $347.589,63$ \\
\hline TK Luar Keluarga & $\mathrm{Rp}$ & & & $537.472,22$ & & $1.289 .933,33$ \\
\hline Biaya Sewa Lahan & $\mathrm{Rp}$ & & & $401.851,85$ & & $964.444,44$ \\
\hline Total Biaya Tunai & $\mathrm{Rp}$ & & & $1.758 .702,37$ & & $4.220 .885,68$ \\
\hline \multicolumn{7}{|l|}{ II. Biaya Diperhitungkan } \\
\hline TK Dalam Keluarga & $\mathrm{Rp}$ & & & $1.536 .648,15$ & & $3.687 .955,56$ \\
\hline Penyusutan alat & $\mathrm{Rp}$ & & & $85.371,64$ & & $204.891,94$ \\
\hline Total Biaya Diperhitungkan & & & & $1.622 .019,79$ & & $3.892 .847,50$ \\
\hline III. Total Biaya & $\mathrm{Rp}$ & & & $3.380 .722,16$ & & $8.113 .733,17$ \\
\hline Pendapatan Atas Biaya Tunai & $\mathrm{Rp}$ & & & $561.992,08$ & & $1.348 .780,99$ \\
\hline Pendapatan Atas Biaya Total & $\mathrm{Rp}$ & & & $(1.060 .027,71)$ & & $(2.544 .066,51)$ \\
\hline $\mathrm{R} / \mathrm{C}$ Atas Biaya Tunai & $\mathrm{Rp}$ & & & 1,32 & & 1,32 \\
\hline R/C Atas Biaya Total & $\mathrm{Rp}$ & & & 0,69 & & 0,69 \\
\hline
\end{tabular}




\section{Pendapatan Rumah Tangga}

Sumber pendapatan rumah tangga petani diperoleh dari pendapatan usahatani atau budidaya (on farm), usahatani di luar kegiatan usahatani (off farm), dan usaha non pertanian (non farm). Rata-rata pendapatan rumah tangga yang diterima petani diperoleh dari gabungan pendapatan dari berbagai sektor tersebut. Sumber pendapatan petani dari kegiatan on farm memiliki kontribusi terbesar diperoleh dari usahatani jagung sebesar 53,83 persen dibandingkan dari sumber pendapatan lain (off dan non farm). Hal ini menunjukkan bahwa petani di Kecamatan Sidomulyo masih mengandalkan pertanian sebagai sumber pendapatan utama mereka. Ini berarti bahwa kegiatan ekonomi di pedesaan masih tetap menempatkan sektor pertanian sebagai sektor yang memegang peranan penting, baik dalam menyerap tenaga kerja maupun dalam menyumbang pendapatan. Pendapatan yang diterima petani responden dari berbagai sumber diharapkan mampu memenuhi kebutuhan rumah tangga petani padi ladang. Pendapatan rata-rata rumah tangga petani per tahun serta kontribusinya dapat dilihat pada Tabel 2.

Rata-rata pendapatan rumah tangga petani padi ladang di Kecamatan Sidomulyo sebesar Rp54.391.349,80/tahun. Petani padi ladang di Kecamatan Sidomulyo memperoleh pendapatan rumah tangga dari kegiatan usahatani padi ladang dan usahatani jagung (on farm) sebesar Rp29.774.158,02, di kegiatan luar usahatani padi ladang (off farm) sebesar Rp23.222.222,22, dan pendapatan di luar kegiatan pertanian (non farm) sebesar Rp1.394.969,56. Hal ini menunjukkan bahwa sektor pertanian merupakan penyumbang terbesar pendapatan petani padi ladang. Pendapatan dari non farm hanya memberikan kontribusi sebesar 2,56 persen dari total pendapatan rumah tangga petani padi ladang.

Kondisi ini berbeda dengan hasil penelitian Murdani, Widjaya, dan Rosanti (2015), diketahui bahwa sumber pendapatan dari usahatani padi memiliki kontribusi terbesar yaitu Rp11.292.223,00 atau 57,64 persen, kemudian yang kedua yaitu sumber pendapatan non padi sebesar Rp5.748.422,00 atau 29,34 persen dan selanjutnya sumber pendapatan yang ketiga yaitu sumber pendapatan non pertanian sebesar Rp2.550.000,00 atau sebesar 13,02 persen.
Tabel 2. Sumber pendapatan rumah tangga petani padi ladang di Kecamatan Sidomulyo

\begin{tabular}{lrr}
\hline No Sumber Pendapatan & Pendapatan (Rp) & $\begin{array}{c}\text { Kontribusi } \\
\text { Terhadap } \\
\text { Pendapatan } \\
\text { Rumah } \\
\text { Tangga (\%) }\end{array}$ \\
\hline 1. On farm : & $29.774 .158,02$ & 54,74 \\
a) Usahatani padi & $494.065,43$ & 0,91 \\
$\quad$ ladang & $29.280 .092,59$ & 53,83 \\
b) Usahatani jagung & $23.222 .222,22$ & 42,69 \\
2. Off farm & $1.394 .969,56$ & 2,56 \\
3. Non farm & $54.391 .349,80$ & 100,00 \\
\hline Total & & \\
\hline
\end{tabular}

\section{Analisis Kesejahteraan Rumah Tangga}

Pengukuran tingkat kesejahteraan rumah tangga berdasarkan kriteria Sajogyo (1976) dilakukan dengan menghitung pengeluaran per kapita per tahun menggunakan standar harga beras per kilogram yang berlaku. Pengeluaran petani padi ladang terdiri dari pengeluaran pangan sebesar 63,95 persen dan pengeluaran non pangan sebesar 36,05 persen. Pengeluaran pangan dibedakan atas pengeluaran untuk bahan pangan pokok, lauk pauk, kacang-kacangan, sayuran, buah-buahan, sumber lemak, makanan jajan, minuman, dan pengeluaran untuk bumbu-bumbuan. Pengeluaran non pangan terdiri dari bahan bakar, rekreasi, keperluan mandi, sosial, dan keperluan lainnya.

Pengeluaran total rata-rata rumah tangga petani padi ladang di Kecamatan Sidomulyo adalah sebesar Rp25.485.745,00/tahun, yang terdiri dari pengeluaran untuk kebutuhan pangan sebesar Rp16.297.583,00/tahun dan pengeluaran untuk non pangan sebesar Rp9.188.162,00/tahun. Pengeluaran petani padi ladang untuk kebutuhan pangan lebih besar dibandingkan untuk pengeluaran non pangan. Pengeluaran rumah tangga akan mempengaruhi tingkat kesejahteraan petani.

Tingkat kesejahteraan rumah tangga diperoleh dari pengeluaran rumah tangga per kapita per tahun. Pengeluaran rumah tangga per kapita per tahun adalah total pengeluaran rumah tangga petani, baik pengeluaran pangan maupun non pangan dalam setahun dibagi jumlah tanggungan keluarga. Total pengeluaran rumah tangga kemudian dikonversikan ke dalam ukuran setara beras per kilogram, untuk mengetahui tingkat kemiskinan rumah tangga.

Untuk melihat tingkat kesejahteraan petani responden dapat digolongkan ke dalam enam 
golongan. Sebaran golongan tingkat kesejahteraan petani padi ladang disajikan pada Tabel 3 .

Berdasarkan Tabel 3, terdapat rumah tangga petani di Kecamatan Sidomulyo yang masih tergolong kategori nyaris miskin sebesar 7,40 persen, kategori cukup sebesar 90,74 persen dan kategori hidup layak sebesar 1,85 persen. Kondisi ini berbeda dengan hasil penelitian Sari, Haryono, dan Rosanti (2014), bahwa sebagian besar rumah tangga petani jagung di Kecamatan Natar berada pada kriteria cukup (60,78 persen), sedangkan dalam kategori nyaris miskin sebesar 15,69 persen, dan dalam kategori hidup layak sebesar 23,53 persen.

Bank Dunia dalam mengukur kemiskinan menggunakan garis kemiskinan internasional. Bank Dunia menetapkan garis kemiskinan sebesar US\$ 1 per kapita per hari artinya dianggap miskin di dunia, di negara manapun individu tersebut apabila pengeluaran perkapita/hari kurang dari US\$ 1 (Todaro 2000). Sebaran petani berdasarkan tingkat kemiskinan Bank Dunia disajikan pada Tabel 4.

Berdasarkan indikator Bank Dunia, terdapat 40 orang petani yang tidak miskin dengan persentase 74,07 persen dan 14 orang petani yang masuk dalam kategori miskin dengan persentase 25,92 persen. Pengeluaran rata-rata petani di Kecamatan Sidomulyo Rp15.650,00 per kapita per hari dan sebagian besar petani termasuk dalam kategori tidak miskin. Kondisi ini berbeda dengan hasil penelitian Setiani, Zakaria, Adawiyah (2015), sebagian besar petani masuk dalam kategori miskin.

Tabel 3. Sebaran golongan tingkat kesejahteraan petani padi ladang

\begin{tabular}{|c|c|c|c|c|}
\hline No & Golongan & Interval Skor & $\begin{array}{l}\text { Jumlah } \\
\text { (Orang) }\end{array}$ & $\begin{array}{c}\text { Persentase } \\
(\%)\end{array}$ \\
\hline 1. & $\begin{array}{l}\text { Paling } \\
\text { Miskin }\end{array}$ & $\begin{array}{l}<180 \mathrm{~kg} \text { setara } \\
\text { beras/tahun }\end{array}$ & 0 & 0,00 \\
\hline 2. & $\begin{array}{l}\text { Miskin } \\
\text { Sekali }\end{array}$ & $\begin{array}{l}181-240 \mathrm{~kg} \text { setara } \\
\text { beras/tahun }\end{array}$ & 0 & 0,00 \\
\hline 3. & Miskin & $\begin{array}{l}241-320 \mathrm{~kg} \text { setara } \\
\text { beras/tahun }\end{array}$ & 0 & 0,00 \\
\hline 4. & $\begin{array}{l}\text { Nyaris } \\
\text { Miskin }\end{array}$ & $\begin{array}{l}321-480 \mathrm{~kg} \text { setara } \\
\text { beras/tahun }\end{array}$ & 4 & 7,40 \\
\hline 5. & Cukup & $\begin{array}{l}481-960 \mathrm{~kg} \text { setara } \\
\text { beras/tahun }\end{array}$ & 49 & 90,74 \\
\hline 6. & $\begin{array}{l}\text { Hidup } \\
\text { Layak }\end{array}$ & $\begin{array}{l}>960 \mathrm{~kg} \text { setara } \\
\text { beras/tahun }\end{array}$ & 1 & 1,85 \\
\hline \multicolumn{3}{|c|}{ Total } & 54 & 100,00 \\
\hline
\end{tabular}

Tabel 4. Sebaran petani padi ladang berdasarkan tingkat kemiskinan Bank Dunia di Kecamatan Sidomulyo

\begin{tabular}{cccc}
\hline No & \multicolumn{1}{c}{ Kategori } & $\begin{array}{c}\text { Jumlah } \\
(\text { Orang) }\end{array}$ & Persentase (\%) \\
\hline 1. & Tidak Miskin $>1 \$$ & 40 & 74,07 \\
2. & Miskin <1\$ & 14 & 25,92 \\
\hline Jumlah & 54 & 100,00 \\
\hline
\end{tabular}

\section{KESIMPULAN}

Usahatani padi ladang di Kecamatan Sidomulyo, Kabupaten Lampung Selatan tidak menguntungkan dengan nilai $\mathrm{R} / \mathrm{C}$ atas biaya total sebesar 0,69. Pendapatan rumah tangga petani padi ladang di Kecamatan Sidomulyo, Kabupaten Lampung Selatan yang memiliki kontribusi paling besar adalah pendapatan on farm (usahatani padi ladang dan usahatani jagung) sebesar 54,74 persen dari keseluruhan pendapatan rumah tangga. Tingkat kesejahteraan rumah tangga petani padi ladang berdasarkan kriteria Sajogyo (1976), sebagian besar petani termasuk dalam kategori cukup dan berdasarkan kriteria Bank Dunia sebagian besar petani termasuk dalam kategori tidak miskin.

\section{DAFTAR PUSTAKA}

Agunggunanto EY, Saptanto, dan Apriliani S. 2011. Analisis kemiskinan dan pendapatan keluarga nelayan kasus di Kecamatan Wedung Kabupaten Demak Jawa Tengah, Indonesia. Jurnal Dinamika Ekonomi Pembangunan, 1 (1): 50-58. https://blognyae konomi.files.wordpress.com/2013/06/1658-37 22-1-pb.pdf. [21 September 2017].

BPS [Badan Pusat Statistik]. 2016. Produksi tanaman padi ladang menurut Kabupaten/Kota di Provinsi Lampung, tahun 2014-2015. http://lampung.bps.go.id/linkTa belStatis/view/id/447. [30 Oktober 2016].

BPS [Badan Pusat Statistik] Kabupaten Lampung Selatan. 2016. Luas Panen dan Produksi tanaman padi ladang menurut Kecamatan di Kabupaten Lampung Selatan, tahun 2016. https://lampungselatankab.bps.go.id/dynamic table/2017/01/23/44/.html. [30 Oktober 2016].

BPS [Badan Pusat Statistik] Provinsi Lampung. 2016. Produksi tanaman padi ladang menurut kabupaten/kota di Provinsi Lampung, tahun 2014-2015. http://lampung. bps.go.id/linkTabelStatis/view/id/447. Oktober 2016].

Damardjati DS, Marwoto DKS, Swastika DM, dan Hilman Y. 2005. Prospek dan Arah Pengembangan Agribisnis Kedelai. Badan 
Litbang Pertanian, Departmen Pertanian. Jakarta.

Isaac S dan Michael WB. 1995. Handbook in Research and Evaluation. EdITS Publishers. San Diego.

Mantra IB. 2004. Demografi Umum. Penerbit Pustaka Pelajar. Jakarta.

Murdani MI, Widjaya S, dan Rosanti N. 2015. Pendapatan dan tingkat kesejahteraan rumah tangga petani padi (Oryza Sativa) di Kecamatan Gadingrejo Kabupaten Pringsewu. JIIA, 2 (3): 246-252. http://jurnal.fp.unila.ac. $\mathrm{id} / \mathrm{index}$. php/JIA/article/ view/1035/940. [20 Mei 2017].

Purba HM. 2005. Analisis pendapatan dan Faktor-faktor yang Mempengaruhi Produksi Cabang Usahatani Padi Ladang di Kabupaten Karawang. Skripsi. Fakultas Pertanian. Institut Pertanian Bogor. [20 Mei 2017].

Putri TL, Lestari DAH, dan Nugraha A. 2013. Pendapatan dan kesejahteraan petani padi organik peserta Sekolah Lapangan Pengelolaan Tanaman Terpadu (SL-PTT) di Kecamatan Pagelaran Kabupaten Pringsewu. JIIA, 1 (3): 226-231. http://jurnal.fp.unila.ac. id/index.php/JIA/article/view/577/539. [20 Mei 2017].

Rahim ABD dan Hastuti DRD. 2008. Ekonomika Pertanian (Pengantar, Teori dan Kasus). Penebar Swadaya. Jakarta.
Sajogyo. 1976. Pertanian, Landasan Tolak Bagi Pengembangan Bangsa Indonesia. Kata Pengantar dalam Clifford Geertz,

"Involusi Pertanian: Proses Perubahan Ekologi di Indonesia”. Bhratara Karya Aksara. Jakarta.

Sari DK, Haryono D, dan Rosanti N. 2014. Analisis pendapatan dan tingkat kesejahteraan rumah tangga petani jagung di Kecamatan Natar Kabupaten Lampung Selatan. JIIA, 2 (1): 64-70. http://jurnal.fp.unila.ac.id/index. php/JIA/article/view/562/524. [20 Mei 2017].

Setiani N, Zakaria WA, dan Adawiyah R. 2015. Analisis usahatani pada beberapa pola tanam di lahan sawah dan hubungannya dengan tingkat pendapatan dan kesejahteraan rumah tangga petani di Kecamatan Abung Surakarta Kabupaten Lampung Utara. JIIA, 3 (2): 122129. http://jurnal.fp.unila.ac.id/index.php/JIA /article/view/1030/935. [20 Mei 2017].

Singarimbun M dan Effendi S. 1995. Metode Penelitian Survei. PT Pustaka LP3ES Indonesia. Jakarta

Soekartawi. 1995. Analisis Usahatani. Penerbit Universitas Indonesia (UI-Press). Jakarta.

Sukirno S. 2005. Mikro Ekonomi Teori Pengantar Edisi ketiga. PT Raja Grafindo Persada. Jakarta.

Todaro MP. 2000. Pembangunan Ekonomi. Erlangga. Jakarta. 